\title{
Rig Time Reduction During Kick Handling Operation in Exploration Well X by Applying Drillers Method
}

\author{
Bambang Yudho Suranta ${ }^{1, *}$ Akhmad Sofyan ${ }^{1}$ Didin Chaerudin Irwansyah ${ }^{1}$ \\ ${ }^{I}$ Oil and Gas Production Engineering, Polytechnic of Energy and Mineral Akamigas, Cepu Blora-Central Java, \\ Indonesia \\ "Corresponding author. Email: yudho_bys@yahoo.com
}

\begin{abstract}
This journal will describe how the kick handling time is reduced from the actual condition by applying Drillers The method in Well X. This well is an exploration well with the main objective at the 9,000 ft range of depth in Kujung Formation, which has been identified as a gas hydrocarbon reservoir zone. Before reaching the total depth, the drilling operation involves four kick occurrences. This Kick happened for the last time at the depth of 8,525 ft and it needed two times kill mud circulation to handle the kick. Furthermore, the time needed to control the kick was 13.5 hours by applying the Engineers Method. Moreover, even the well control operation was successfully done, Engineers Method may cause some serious problems since this method allows gas migration to the surface without expansion when the kill mud preparation needs a longer time. Thus, this method is evaluated with the Drillers Method as the comparison, resulting in the recommendation of a well control method for Exploration Well $\mathrm{X}$ by considering the kick handling time, produced pressure, operational complexity, and hole problem aspect. Then the recommended well control method is simulated with Landmark software to predict the produced pressure during the well control operation in Exploration Well X. Through this recommendation, kick handling time in Exploration Well X is reduced to be 4.3 hours only with 69,493.39 USD of cost-saving.
\end{abstract}

Keywords: Kick, Well Control, Drillers Method, Engineers Method, Blowout.

\section{INTRODUCTION}

Kick is a process of unexpected formation fluid invasion to the wellbore, whether it is gas, oil, or formation water fluid. If the kick is not well handled, the kick will cause several further serious problems. These problems include fractured formation and the most dangerous one for the surrounding environment is the blowout. Thus, the well control method is important to be applied. Well control method is a method to control the kick so that the kick will not cause various further problems. The well control method consists of two main types, circulating and noncirculating method. The circulating method is used to control the kick when the drilling operation is conducted. The circulation method divided into three types, Drillers Method, Engineers Method, and Concurrent Method. The well control method selection for the most common circulating method to control the kick, Drillers Method and Engineers Method, in a highly pressured well will be delivered through this journal.
The background of this journal research is the kick problem during a drilling operation in " $\mathrm{Y}$ " Field. " $\mathrm{Z}$ " Company have conducted 9 drilling campaigns in "Y" Field. Four wells, out of those 9 wells, suffered kick, and one of them needed to be solved through a relief well drilling. This occurrence was caused by the underground blowout disaster while handling the kick (annulus pressure higher than the allowable surface pressure, causing fractured formation below the casing shoe). From the description above, it is known that kick is the main drilling problem during the drilling campaign in "Y" Field and the company needs to solve this problem. The recommendation given by this journal would be the most suitable circulating well control method that will produce the most effective annular pressure, handling time, and operational complexity compared to the other circulating method to prevent the fractured formation below the casing shoe whilst solving the kick well. 


\section{METHOD}

The qualitative descriptive method will be used as the research method in this journal. The research sequence begins with data collection to calculate well control basic calculations and resulted pressure from those well control methods. After that, Drillers Method and Engineers Method are compared based on previous calculations. The comparisons include kick handling time, produced circulation pressure of the well control method, operational complexity and the potential hole problem when the well under static condition. Next, the most effective well control method is chosen to handle the kick during Exploration Well X drilling operation.

\section{RESULT AND DISCUSSION}

Table 1a. Exploration Well X D-Exponent (1/2)

\subsection{Actual Handling}

Well $\mathrm{X}$ is a wildcat well which has a purpose to gain Kujung Formation data. During the drilling operation, kick occurred in many times and finally the drilling contractor decided to end the drilling operation with a safety reason. Then, the well was cemented with the depth of approximately $9,000 \mathrm{ft}$.

After cementing the $9-5 / 8 "$ casing, the drilling operation was continued with 8-1/2" drill bit to drill $2 \mathrm{ft}$ depth of formation to do the LOT. The LOT resulted 16.7 ppg of EMW pressure. Then, the drilling operation was continued to drill until the desired depth. When reaching the depth of $8,525 \mathrm{ft}$, kick happened during drilling operation with $15.2 \mathrm{ppg}$ after experiencing drilling break and dexponent trend decline (Table 1 and Figure 1). The well was shut in.

\begin{tabular}{llllll}
$\begin{array}{l}\text { Depth } \\
\mathrm{ft}\end{array}$ & $\begin{array}{l}\text { ROP } \\
\mathrm{ft} / \mathrm{h}\end{array}$ & $\begin{array}{l}\text { RPM } \\
\mathrm{rpm}\end{array}$ & $\begin{array}{l}\text { WOB } \\
\mathrm{klb}\end{array}$ & $\begin{array}{l}\text { Hole Size } \\
\text { inch }\end{array}$ & D-Exp \\
\hline 8,410 & 6 & 100 & 28 & 8.5 & 2.128 \\
8,450 & 6 & 100 & 28 & 8.5 & 2.128 \\
8,490 & 6 & 100 & 28 & 8.5 & 2.128 \\
8,510 & 6 & 100 & 28 & 8.5 & 2.128 \\
8,525 & 90 & 100 & 28 & 8.5 & 1.299 \\
\hline
\end{tabular}

Table 1b. Exploration Well X D-Exponent (2/2)

\begin{tabular}{lllll} 
Normal Pressure & Mud Weight & D-Exp & \multicolumn{2}{c}{ Pore Pressure Estimation } \\
ppg & ppg & & psi & 14.9 \\
9 & 15.2 & 1.260 & 6,517 & 14.9 \\
9 & 15.2 & 1.260 & 6,548 & 14.9 \\
9 & 15.2 & 1.260 & 6,579 & 14.9 \\
9 & 15.2 & 1.260 & 6,594 & 15.6 \\
9
\end{tabular}

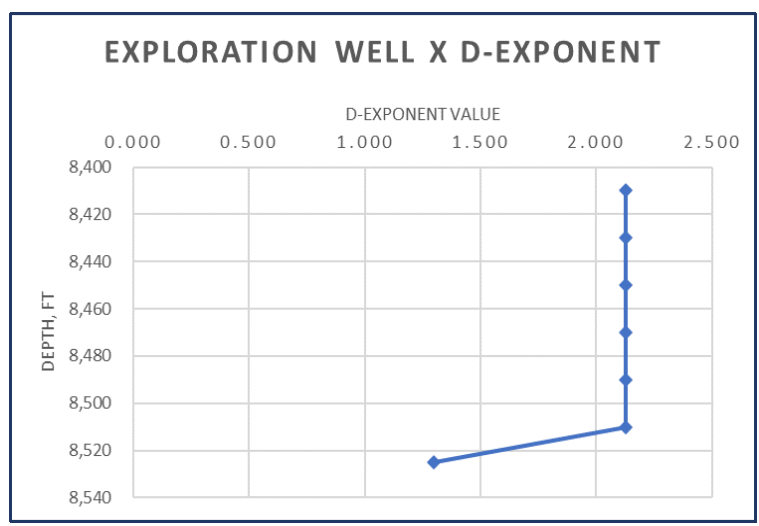

Figure 1 D-Exponent Trend Decline of 8.5" Exploration Well X Section

After a while, SIDP showed 150 psi and SICP 250 psi. Then the mix and replace method was done to mix the killing mud, resulting 15.5 ppg of first killing mud.
Mix and replace method is a method to mix the mud in the kill/reserve tank with the one in the active tank to increase the mud weight. The removed mud volume in the active tank then replaced to another tank instead of dump it to the disposal pit. This method was chosen because there was a volume of heavy mud in the kill tank. When the kick came the bit was in on bottom condition, thus the circulating well control method was reliable to be done. When the well is flowing, only drillcollar and the bit exist in the open hole. The mud resulted from mix and replace method then was circulated to the well using Engineers Method. But, the well kept flowing (when the pump was shut off) and then shut in.

After that, the mud weight was increased to $15.7 \mathrm{ppg}$ by adding barite in active tank. This method was done because there was no more kill mud in the kill tank. Then, the new kill mud was circulated to the well. The kick was well handled and the well was static. Based on the drilling 
parameters analysis (d-exponent), the predicted formation pressure in this zone is 6,916 psi. The kick handling time, based on the daily drilling report, was 13.5 hours. The scheme and table below show the detailed of Well X kick handling process with the time spent.

\subsection{Kick Handling Recommendation Analysis}

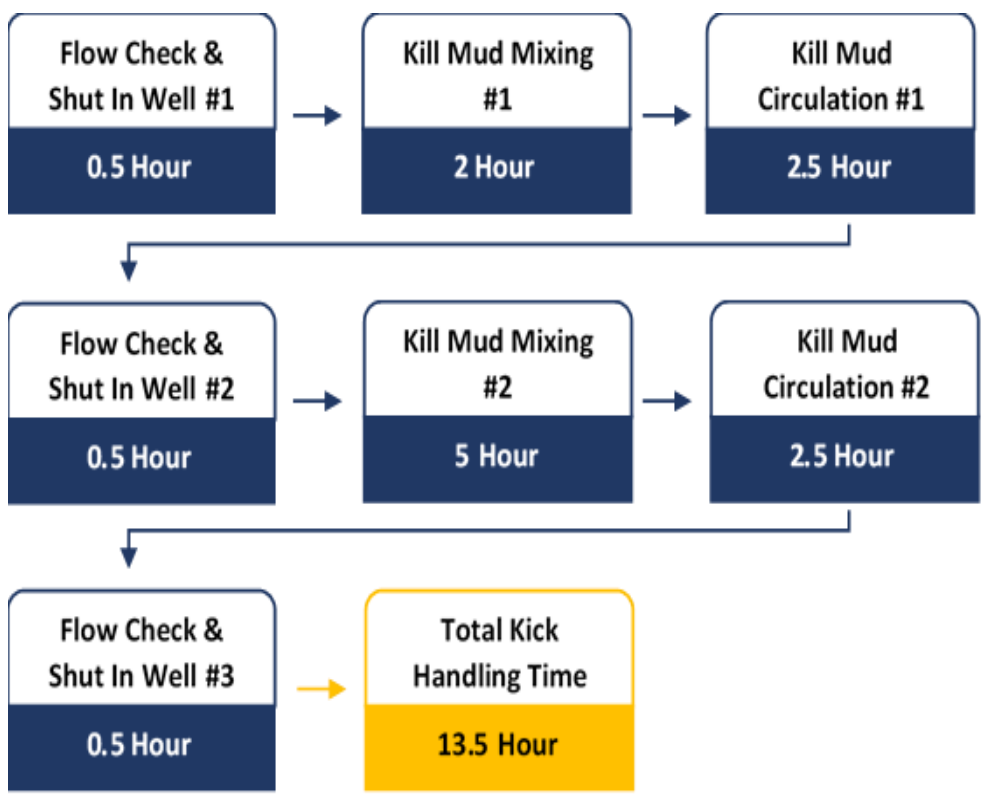

Figure 2 Actual Kick Handling Scheme

Table 2. Kick Handling Time for Well X

\begin{tabular}{llcc}
\multicolumn{1}{c}{ Activity } & & \multicolumn{2}{c}{ Duration } \\
\hline Circulation (One Full Circulation) & & hrs & mnt \\
& First & 2.5 & 150 \\
KMW Mixing Time & Second & 2.5 & 150 \\
& Weight 1 & 2 & 120 \\
Flow Check \& Shut In (3x) & Weight 2 & 5 & 300 \\
Total Time & & 1.5 & 90 \\
\hline
\end{tabular}

Table 3. Exploration Well X Data

\begin{tabular}{|c|c|c|c|c|}
\hline Data Type & \multicolumn{2}{|l|}{ Data } & Value & Unit \\
\hline \multirow[t]{10}{*}{ Well Data } & \multirow[t]{3}{*}{ Hole } & Diameter & 8.5 & in \\
\hline & & Depth MD & 8,525 & $\mathrm{ft}$ \\
\hline & & Depth TVD & 8,525 & $\mathrm{ft}$ \\
\hline & \multirow[t]{4}{*}{ Casing } & Outside Diameter & 9.625 & in \\
\hline & & Inside Diameter & 8.535 & in \\
\hline & & Depth MD & 8,410 & $\mathrm{ft}$ \\
\hline & & Depth TVD & 8,410 & $\mathrm{ft}$ \\
\hline & \multirow[t]{2}{*}{ LOT } & Mud Weight & 15.2 & ppg \\
\hline & & Surface Test Pressure & 670 & psi \\
\hline & \multicolumn{2}{|c|}{ Pore Pressure } & 6,916 & psi \\
\hline Mud Data & \multicolumn{2}{|c|}{ Current Mud Weight } & 15.2 & ppg \\
\hline
\end{tabular}




\begin{tabular}{|c|c|c|c|c|}
\hline Data Type & \multicolumn{2}{|l|}{ Data } & Value & Unit \\
\hline & \multicolumn{2}{|c|}{ Active Piping Surface Volume } & 3 & bbl \\
\hline \multirow[t]{3}{*}{ Pump Data } & \multicolumn{2}{|c|}{ Pump Displacement } & 0.1428 & $\mathrm{bbl} / \mathrm{stroke}$ \\
\hline & \multirow[t]{2}{*}{ Pump Output } & Stroke & 80 & SPM \\
\hline & & Pressure & 1,400 & psi \\
\hline \multirow[t]{4}{*}{ Kick Data } & \multicolumn{2}{|c|}{ Shut In Casing Pressure (SICP) } & 250 & psi \\
\hline & \multicolumn{2}{|c|}{ Shut In Drillpipe Pressure (SIDPP) } & 150 & psi \\
\hline & \multicolumn{2}{|l|}{ Pit Gain } & 10 & bbl \\
\hline & \multicolumn{2}{|l|}{ Kick Time } & $11 \mathrm{AM}$ & $(\mathrm{GMT}+7)$ \\
\hline \multirow[t]{5}{*}{ Drillstring Data } & \multirow{2}{*}{ DP } & Length & 7,947 & $\mathrm{ft}$ \\
\hline & & Capacity & 0.0178 & $\mathrm{bbl} / \mathrm{ft}$ \\
\hline & \multirow{2}{*}{ HWDP } & Length & 390 & $\mathrm{ft}$ \\
\hline & & Capacity & 0.0088 & $\mathrm{bbl} / \mathrm{ft}$ \\
\hline & DC & Length & 188 & $\mathrm{ft}$ \\
\hline
\end{tabular}

Table 4 and 5 show the calculation results.

Table 4. Well Control Parameters for Drillers Method \& Engineers Method

\begin{tabular}{|c|c|c|c|}
\hline No & Parameter & Value & Unit \\
\hline 1 & Kill Mud Weight & 15.6 & ppg \\
\hline 2 & Initial Circulating Pressure & 1,550 & psi \\
\hline 3 & Final Circulating Pressure & 1,437 & psi \\
\hline 4 & Drillstring Volume & 145.5 & bbl \\
\hline 5 & Annulus Volume & 393.4 & bbl \\
\hline 6 & Total Active Volume & 541.9 & bbl \\
\hline 7 & Surface to Bit Stroke & 1,019 & stroke \\
\hline 8 & Surface to Bit Time & 12.8 & minute \\
\hline 9 & Bit to Surface Stroke & 2,775 & stroke \\
\hline 10 & Bit to Surface Time & 34.5 & minute \\
\hline 11 & One Circulation Stroke & 3,774 & stroke \\
\hline 12 & One Circulation Time & 47.2 & minute \\
\hline 13 & MAMW & 16.7 & ppg \\
\hline 14 & MAASP & 655 & psi \\
\hline 15 & Kick Tolerance & 32.5 & bbl \\
\hline 16 & Minimum Kill Mud Volume & 700.0 & bbl \\
\hline 17 & Pressure Drop & 12 & psi/stroke \\
\hline
\end{tabular}

\subsubsection{Kick Handling Time}

Table 5. Drillpipe Pressure Schedule for Well X

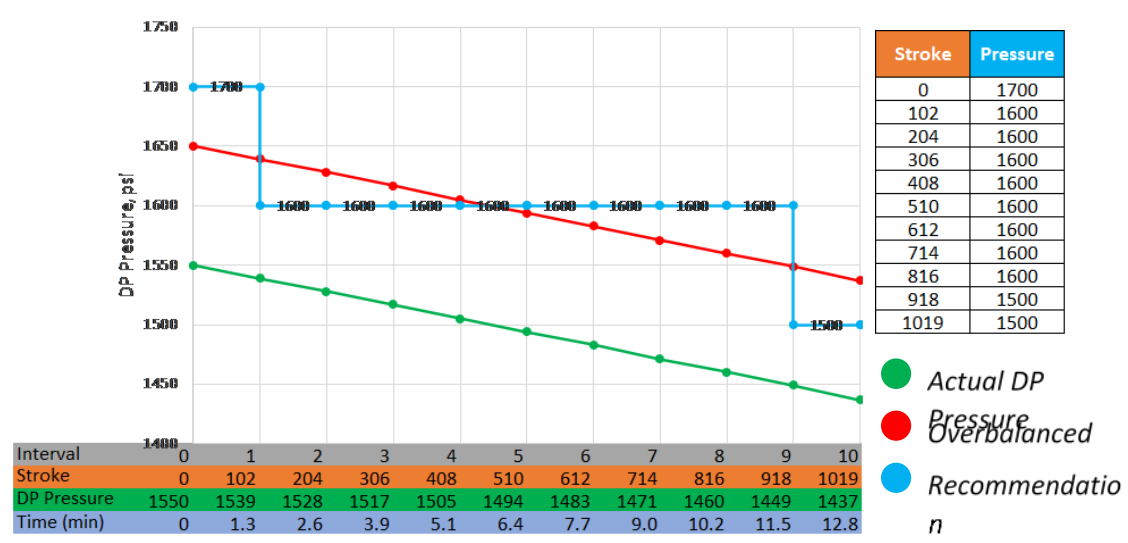


The time to handle the kick consist of the time to check flow and shut in the well, mix the kill mud, and circulate the kill mud as much as the number of circulations needed by proposed well control method.

\subsubsection{Check Flow and Shut In Well}

The time to check flow and shut in the well are based on the actual time in Exploration Well $\mathrm{X}$, which is 0.5 hour or 30 minutes. This range of time consist of 15 minutes to shut in well and 15 minutes to observe the casing and drillpipe pressure.

\subsubsection{Kill Mud Mixing}

The time to mix the kill mud is different with the actual time. In this recommendation the kill mud mixing time is resulted based on the 2 actual conditions that might occur, which is (i) there was no kill mud in the kill tank and (ii) there were volume of kill mud in the kill tank, but the density of the mud is not dens enough to produce the required kill mud weight (KMW).

For the first condition, the only method to produce the KMW was by adding the barite to the mud in the active tank. Based on equation 1, the number of barites required to produce $700.0 \mathrm{bbl}$ of mud (minimal required volume of mud) with density from $15.2 \mathrm{ppg}$ to be $15.6 \mathrm{ppg}$ is 238 sacks. With the barite mixing rate of 2.679 minute every sack, the mixing time for this first method is 639.4 minutes or 10.7 hours.

Barite Requirement $=\frac{1470\left(\mathrm{~W}_{2}-\mathrm{W}_{1}\right)}{35-\mathrm{W}_{2}} \times \frac{\mathrm{KMW} \text { Volume }}{100}$

For the second condition (there were volume of kill mud in the kill tank, but the density of the mud is not dens enough to produce the required kill mud weight (KMW)), there are 2 reliable methods. First by adding barite to heavy mud in the kill tank so the further mixing with the mud in the active tank will result the required KMW. Then the heavy mud in the kill tank is mixed with the one in the active tank by applying mix and replace method. Mix and replace method is a method to produce KMW by transferring the heavy mud in the kill tank to the active tank by using hopper, but before the mixing can be done the volume of less dens mud in the active tank must be replaced to the other tank instead of dump it to disposal pit. The initial mud condition in the active tank was 15.2 ppg with volume of $600.0 \mathrm{bbl}$, while in the kill tank was $15.6 \mathrm{ppg}$ with volume of $500.0 \mathrm{bbl}$. The applicated hopper rate is $450 \mathrm{bbl} /$ hour. Based on equation 2, below is the mix and replace program for this second method.

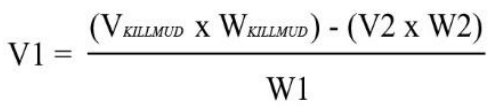

Table 6. Mix and Replace Program \#1

\begin{tabular}{|c|c|c|c|}
\hline Parameter & Variable & Value & Unit \\
\hline Mud & Mud Volume 1 (V1) & 200.0 & bbl \\
\hline Volume and & Mud Weight 1 (W1) & 15.2 & ppg \\
\hline \multirow[t]{4}{*}{ Weight } & Mud Volume 2 (V2) & 500.0 & bbl \\
\hline & Mud Weight 2 (W2) & 15.8 & ppg \\
\hline & Kill Mud Volume & 700.0 & bbl \\
\hline & Kill Mud Weight & 15.6 & ppg \\
\hline Mix and & Hopper Rate & 450.0 & bbl/hours \\
\hline Replace & Mix and & & \\
\hline \multirow[t]{3}{*}{ Time } & Replace & 1.1 & hours \\
\hline & Duration & & \\
\hline & Total & 1.1 & hours \\
\hline
\end{tabular}

Based on the program above, the heavy mud in the kill tank is 0.2 ppg less dens to produce required KMW. Thus, additional weight by adding barite is needed. Based on equation 1 , the number of barites needed to increase the mud weight from $15.6 \mathrm{ppg}$ to $15.8 \mathrm{ppg}$ with volume of $500.0 \mathrm{bbl}$ is 39 sacks with mixing duration of 112.9 minutes or 1.9 hours. Thus, the total time needed to apply this second mixing method is 3.0 hours or 180.0 minutes.
The second method for the second condition is by doing mix and replace method first, and then adding barite to the produced mud in the active tank to produce $\mathrm{KMW}$. Below is the mix and replace program for this method. 
Table 7. Mix and Replace Program \#2

\begin{tabular}{llll} 
Parameter & Variable & Value & Unit \\
\hline Mud & Mud Volume 1 (V1) & 200.0 & $\mathrm{bbl}$ \\
Volume & Mud Weight 1 (W1) & 15.2 & $\mathrm{ppg}$ \\
and & Mud Volume 2 (V2) & 500.0 & $\mathrm{bbl}$ \\
Weight & Mud Weight 2 (W2) & 15.7 & $\mathrm{ppg}$ \\
& Kill Mud Volume & 700.0 & $\mathrm{bbl}$ \\
& Kill Mud Weight & 15.5 & $\mathrm{ppg}$ \\
\hline Mix and & Hopper Rate & 450.0 & $\mathrm{bbl} / \mathrm{hours}$ \\
Replace & Replacing Duration & 0.9 & hours \\
Time & Mixing Duration & 1.1 & hours \\
& Total & 2.0 & hours \\
\hline
\end{tabular}

Based on equation 1, the number of required barites to produce KMW from the program above is 54 sacks with mixing duration of 156.4 minutes and 2.7 hours. Thus, the total time to do this third method is 4.7 hours or 282.0 minutes.

Table 8. Kill Mud Mixing Time Summary

\begin{tabular}{llcc} 
Method & Activity & Duration & hrs \\
mnt & 10.7 & 639.4 \\
Method 1 & Barite Addition & 3.0 & 180.0 \\
Method 2 & Barite Addition + Mix and Replace & 4.7 & 282.0 \\
Method 3 & Mix and Replace + Barite Addition & 4.0 \\
\hline
\end{tabular}

Based on the mixing time, the second method is chosen as the recommended mixing method to handle the kick in Exploration Well $\mathrm{X}$ because it is the fastest method among 2 others. The faster kick handling time, the faster well under control and the drilling operation can be continued.

\subsubsection{Circulation Time}

Tabel 9. Kill Mud Time Summary

\begin{tabular}{lcccc}
\hline \multirow{2}{*}{ Activity } & \multicolumn{2}{c}{ Drillers Method } & \multicolumn{2}{c}{ Engineers Method } \\
hrs & mnt & 0.8 & 47.3 \\
\hline Circulation & 1.4 & 81.8 & 3.0 & 180.0 \\
Kill Mud Mixing & 2.4 & 145.5 & 0.5 & 30.0 \\
Check Flow \& Shut In & 0.5 & 30.0 & $\mathbf{4 . 3}$ & $\mathbf{2 5 7 . 3}$ \\
Total & $\mathbf{4 . 3}$ & $\mathbf{2 5 7 . 3}$ & $\mathbf{4 . 3}$
\end{tabular}

Drillers Method needs 2 times circulation consisting of 2 times BTS circulation and 1 times STB circulation, while Engineers Method only needs 1 time circulation consisting of each 1 time circulation of BTS and STB. Refer to table 4, the time needed to do Drillers Method circulation is 81.8 minutes or 1.4 hours and Engineers Method as long as 47.3 minutes and 0.8 hours. Below is the kick handling time by applying Drillers Method and Engineers Method.
The table below shows the time summary of mentioned three mud mixing methods.

\subsubsection{Shut In Well}

Shut in well method is a method to close/secure the well, resulting no more influx flow. When the kick indications like pit gain, mud return flow rate increase, and flowing well when the pump is shut off appears, shut in the well immediately. The reasons of shut in well as immediately as possible:
a. To minimize kick volume
b. To minimize SICP
c. To minimize bottom hole pressure 
d. To train the drilling crew. When there is a doubt, shut in well.

After making a review of shut in well method, the recommendation for shut in well method is able to be determined. Well $\mathrm{X}$ have a pore pressure of $15.6 \mathrm{ppg}$ which is classified as an abnormal pressure. Thus, the recommended shut in well method is soft shut in. The main reason of choosing soft shut in method is to minimize back pressure to the formation which is normally occurred during shut in well operation using hard shut in method. Since the fractured formation makes the well control operation more complicated.

\subsection{Kick Handling Recommendation for Exploration Well $\mathrm{X}$}

The screening process to determine the kick handling method whether applying Drillers or Engineers Method is based on:
a. Kick handling time
b. Produced annulus pressure
c. Operation complexity
d. Hole problem

\subsubsection{Kick Handling Time}

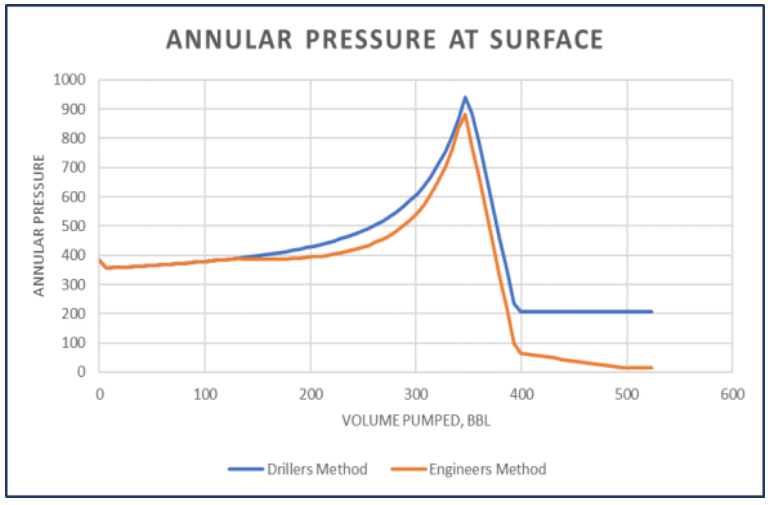

Figure 3 Annular Pressure of Drillers Method Versus Engineers Method

Drillers method needs one circulation more than the Engineers Method. But Engineers Method needs the kill mud to be ready first to start the operation. The kick handling operation needs to be done as early as possible to minimize the risk of influx migration without expansion to the surface. If the influx migrates and reach to the surface without expansion, it will result disastrous high annular pressure in the surface and high bottom hole pressure (BHP) too. This undesirable occurrence may cause fractured formation or pressure barrier equipment failure in the surface.

From the analysis of both methods, the time needed to handle the kick is same between Drillers and Engineers
Method. But, kick handling with Drillers Method can be done earlier than Engineers Method, since the first circulation of Drillers Method can be done without waiting the kill mud ready first. Furthermore, the time for the formation to be exposed by gas influx is minimized and the time given to the gas for migrating without expansion is minimized too. When killing the well with Engineers Method, the gas has a time to migrate without expansion as long as 3.0 hours (kill mud mixing waiting time). This occurrence may cause fractured formation and pressure barrier equipment failure as mentioned before. Thus, Drillers Method is recommended based on kick handling time consideration.

\subsubsection{Produced Annular Pressure}

The produced pressures of Drillers and Engineers Method are simulated in Landmark software referring to the table 4 and 5. Figure 3 shows produced annular pressure comparison between Drillers and Engineers Method.

From the produced annular pressure analysis, the annular pressure resulted by Drillers Method when circulating out the influx is higher than the Engineers Method. This occurrence may cause fractured formation. But, based on the formation breakdown pressure analysis simulation (figure 4) using Landmark software, the annular pressure produced by Drillers Method is not high enough to fracture

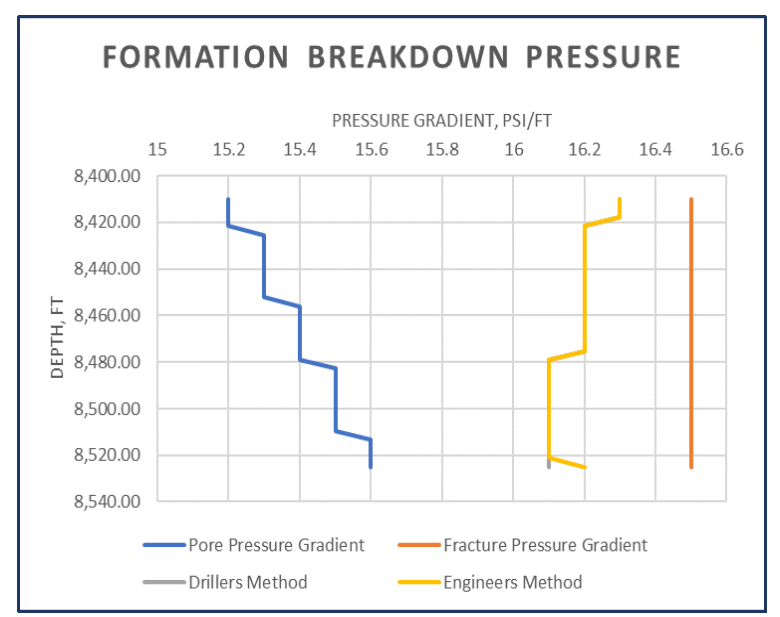

Figure 4 Formation Breakdown Pressure Analysis

the formation below the casing shoe. Thus, Drillers Method is safe (not causing fractured formation) to be used as killing well method in Exploration Well X.

\subsubsection{Operational Complexity}

Based on operational complexity, Engineers Method requires experienced drilling crew. Since there is drillpipe pressure schedule that may confuse all the drilling crews. Thus, Drillers Method is more 
recommended in terms of operational complexity, because of its simple calculation and operation.

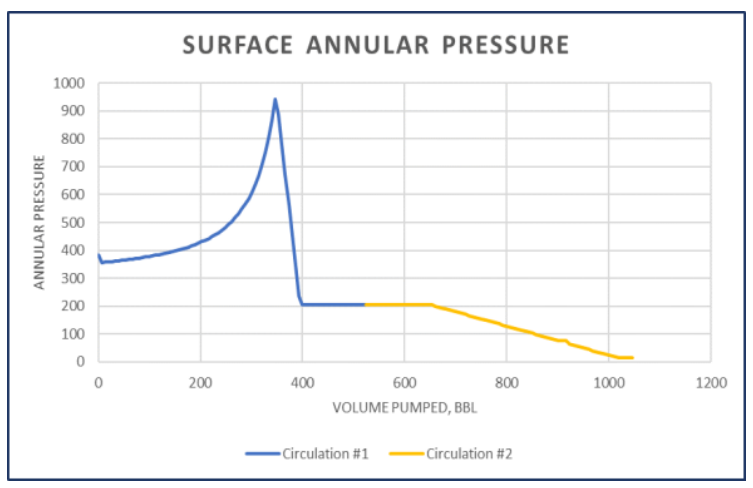

Figure 5 Surface Annular Pressure

\subsubsection{Hole Problem}

During waiting phase of kill mud mixing, the well is in static condition (no circulation and no rotation). The static condition of the well may cause hole problems related to hole instability issues.

But, when drilling the Kujung Formation, the drilling contractor did not find any hole instability problem. Thus, the waiting time for kill mud mixing may not causing formation collapse and this hole problem factor can be neglected.

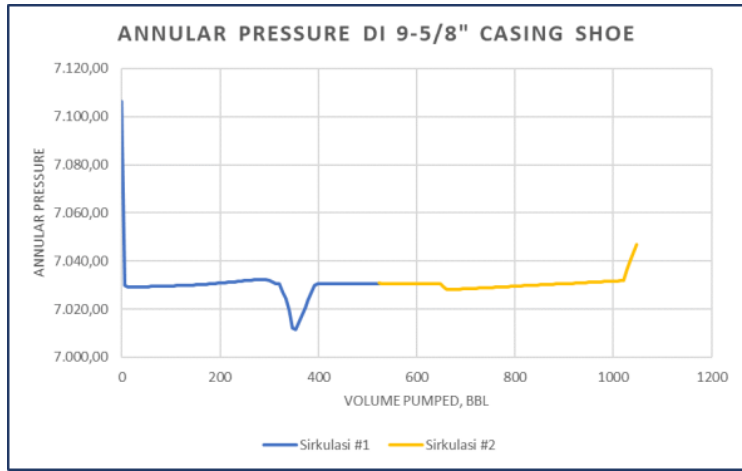

Figure 6 Annular Pressure at Casing Shoe

\subsubsection{Summary}

From the problem analysis above, the recommendation of well control method for Exploration Well X is Drillers Method. Since it will handle the kick earlier, gas migration without expansion will not happen, simple operational activity and there is no hole instability issues.

\subsection{Drillers Method Simulation in Exploration Well X}

Drillers Method operation in Exploration Well X is simulated to analyze the produced annular pressure during circulation by using Landmark software. The data to simulate this operation refers to table 3 and 4 . This simulation must be done to make sure that the well control operation is safe to control the kick in the Exploration Well $\mathrm{X}$ without fracturing the formation or making another problems related to produced pressure (casing burst, BOP failure, etc).

\subsubsection{Annular PressureX}

\subsubsection{Formation Breakdown Pressure}

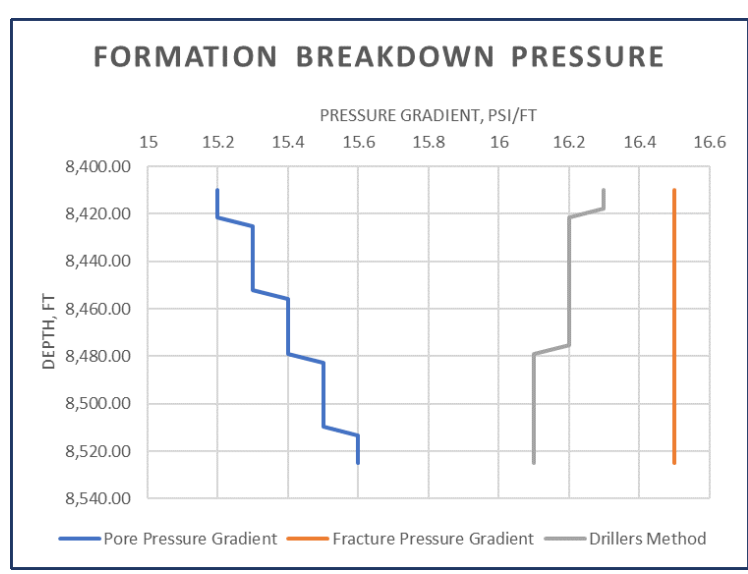

Figure 7 Formation Breakdown Pressure

\subsubsection{Influx Volume}

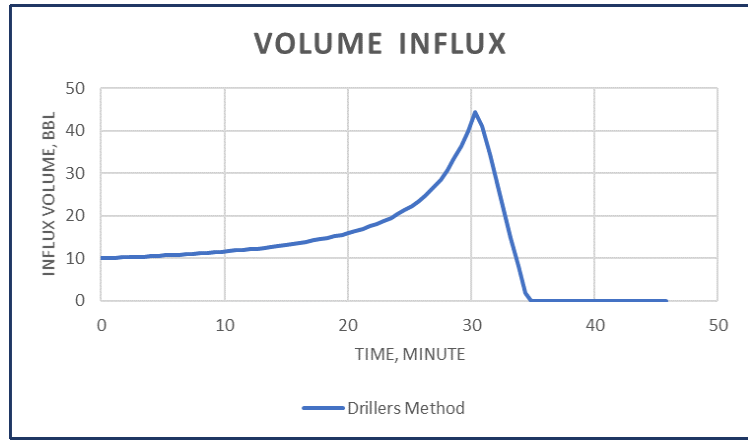

Figure 8 Influx Volume

\subsubsection{Maximum Annular Pressure}

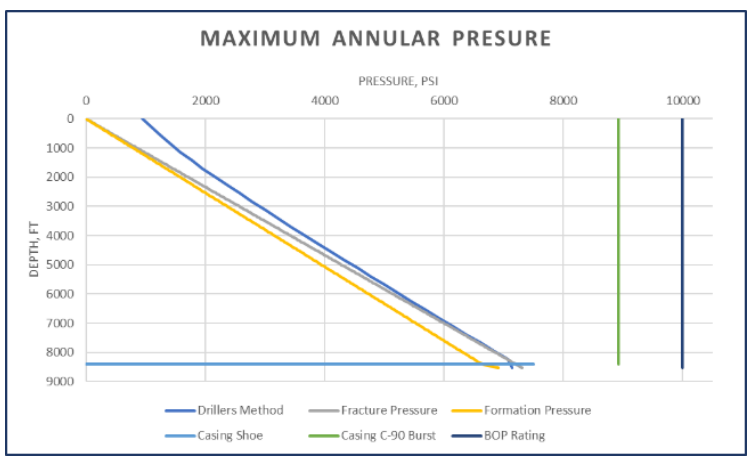

Figure 9 Maximum Annular Pressure 


\subsection{Rig Time Reduction During Kick Handling in Exploration Well $X$}

There is a time reduction during kick handling using recommended well control that has been previously described. This time reduction will result a drilling cost reduction too, since there is a NPT (non productive time) reduction affected by kick handling and will affect the rig hours. Below is the drilling cost efficiency with the recommended kick handling method.

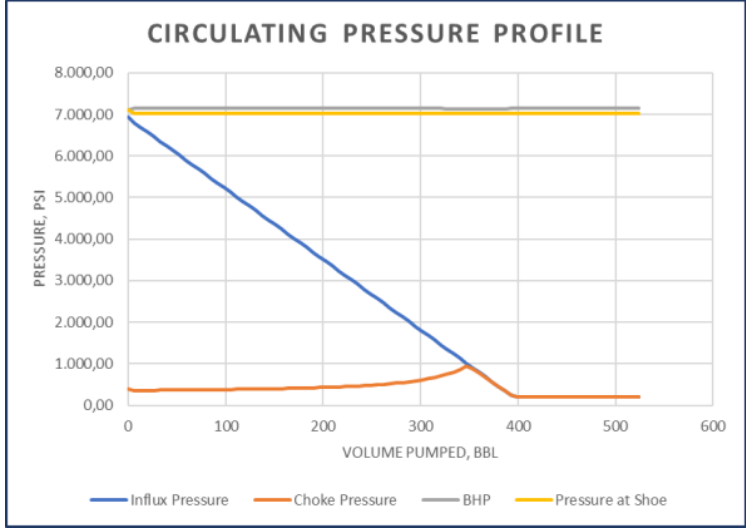

Figure 10 Circulating Pressure Profile

Table 10. Drilling Cost Efficiency by Applying Recommended Well Control Method

\begin{tabular}{|c|c|c|c|}
\hline Kick Handling Method & $\begin{array}{c}\text { Kick Handling Time } \\
\text { hours }\end{array}$ & $\begin{array}{c}\text { Drilling Rig Rate } \\
\text { \$/hours }\end{array}$ & $\begin{array}{c}\text { Total Rig Cost } \\
\$\end{array}$ \\
\hline Actual & 13.5 & 250 & $3,375.00$ \\
\hline Recommendation & 4.3 & 250 & $1,075.00$ \\
\hline Efficiency & 9.2 & & $2,300.00$ \\
\hline
\end{tabular}

Therefore, the total time that can be saved by using recommended method will be 9.2 hours with 2,300 USD of cost more efficient. The drilling rig data is obtained from the 1993 actual 1,500 HP rig daily rate in accordance with the year of Exploration Well X drilling campaign. If that price is converted into today's currency value by multiplying the inflation happened in 19932020 , the 2,300 USD value will equal to $69,493.39$ USD.

\section{CONCLUSION AND SUGGESTION}

\subsection{Conclutions}

1. Kick handling and preparation in Exploration Well X is not optimum yet according to the handling time, number of trial and mud tank arrangement.

2. There are some less precise parameter calculations. These parameters include the kill mud calculation that could not kill the well at the first trial so remedial circulation with new kill mud was needed and the heavy mud in the kill tank that was not dens enough to be mixed with the mud in the active tank to produce the required volume and density of kill mud using mix and replace method resulting kick handling time increase.

3. Mix and replace becomes the fastest kill mud mixing method, despite of quite large capacity of kill tank is needed.

4. The recommendation of well control method for Exploration Well $\mathrm{X}$ is analyzed based on the kick handling time, produced annular pressure during circulating out the influx, operational complexity and hole problem that may come in a static well condition.

5. Drillers Method becomes the most precise method to control the kick in Exploration Well $\mathrm{X}$, since the responsiveness of kick handling, the pressure resulted from its circulation will not fracture the formation and the operation complexity that is simpler than Engineers Method.

6. Based on Landmark software simulation, Drillers Method is safe to be applied as well control method in Exploration Well $\mathrm{X}$ since the produced annular pressure will not causing fractured formation, casing burst or BOP failure.

7. This recommendation of well control method may be used by the company to be a consideration to determine the well control method for the further development wells in Y Field. Because it has been analyzed using literature study and then adapted to the actual condition of the drilling operation. And also will save the kick handling time until 9.2 hours equals with $69,493.39$ USD of rig cost.

\subsection{Suggestions}

1. It is recommended to prepare the reserve heavy mud with density as the MAMW (Maximum Allowable Mud Weight) in the reserve/kill tank as much as the volume of the tank.

2. Because kick is the main drilling problems in the $Y$ Field drilling operation, it should be considered to optimize the kill tank capacity for the reserve heavy 
mud by converting the intermediate tank to be kill tank. Thus, there are enough heavy mud volume to produce required kill mud weight with a number of volumes using mix and replace method.

3. Kick parameter calculations should be optimized to prevent the kick handling remedial operation arrangement.

\section{ACKNOWLEDGMENTS}

The authors would like to sincerely acknowledge all people who have supported us in the writing of this paper

\section{REFERENCES}

[1] C. U. Eni, Drilling Rigs, Libya: Eni Corporate University., 2006.

[2] J. R. Grace, Advanced Blowout \& Well control, Texas: Gulf Publishing Company, 1994.

[3] IADC, Drilling: Well control Manual, IADC, 2019.

[4] J. N. Lapeyrouse, Formulas and Calculations for Drilling, Production, and Workover, New York: Gulf Professional Publishing, 2002. 